\title{
A kromograninok, szekretograninok élettani, kórélettani és klinikai szerepéről
}

\author{
Jakab Lajos dr. \\ Semmelweis Egyetem, Általános Orvostudományi Kar, III. Belgyógyászati Klinika, Budapest
}

"Mortalia facta peribunt."

Horatius

\begin{abstract}
A kromogranin/szekretogranin nagy família eddig megismert alapvető szerkezeti, képződési, kapcsolatrendszeri, funkcionális vonatkozásairól szól a közlemény. Korábban a két famíliatagság egymástól kissé eltérô jellege, funkcionális különbségei voltak előtérben. Majd kiderült, hogy a két famíliatag lényegében azonos szerkezeti, funkcionális, kémiai-biokémiai vegyületeirôl beszélhetünk. A molekuláris szerkezetek döntően aminosavakból és kisebb részben oligoszacharidokból építkeznek. Az eddigiek alapján az is elmondható, hogy acidikus $\mathrm{pH}$-jú, $\mathrm{Ca}^{++}$-ot tartalmazó környezetben képződő, hosszú polipeptidláncokról van szó. Egyes jelentős tagjaik oligoszacharid-csoportokat is tartalmaznak. Ez azért is érdekes, mert az oligoszacharid-láncok (láncvégi sziálsavak) a felismerési és kapcsolódási folyamatokban fontos szereplők. A kromograninok/szekretograninok nagyrészt a neuroendokrin sejtekben képződnek. A sejten belül mitochondrium, endoplasmicus reticulum, szekretorikusgranulum-biogenezis a felépülés útja. Általában stimulus hatására bekövetkezik a szekréció (exocytosis). Ezt a fejlődés következő lépcsője, a sejt-, szövetspecifikus proteolysis követi, ami biológiailag aktív polipeptidláncok képződését eredményezi. Ezek különböző, sajátos tulajdonságok birtokosai. A klinikai hatások is rövid bemutatásra kerülnek, amelyek gyakorlatilag az egész szervrendszert érintik. Tulajdonképpen egy minden szervrendszert magába foglaló, generális szabályozórendszerről van szó, amelynek teljes szerepe, jelentősége még kutatások tárgya.
\end{abstract}

Orv Hetil. 2017; 158(28): 1092-1099.

Kulcsszavak: kromograninok, szekretograninok, élettani, kórélettani vonatkozások

\section{Physiological, pathophysiological and clinical significance of chromogranins / secretogranins}

This paper investigates the fundamental knowledge, build-up, as well as essential structural and important features of the big family of chromogranins/secretogranins. Previously the different properties and the slightly diverging funcional relations of the two family members were in focus. Later on, it has been discovered that they are essentially two similar compounds with identical structures and functions, and they are chemically, biochemically related. From details discovered so far we can tell that they are long polypeptid chains formed from amino acids. Based on insights gained until now we can also state that these compounds are formed in $\mathrm{Ca}^{++}$containing environments with acidic $\mathrm{pH}$. Among the compounds there are several molecules which have characteristic oligosacharid groups. This is especially interesting because oligosacharid chains with sialic acid in terminal position play an important role in the recognising and connectional processes. The chromogranins/secretogranins are mostly formed in neuroendocrine cells, but are also capable of building up in any cell type in the organism during pathological processes. Intracellular biogenesis takes place in the dense endoplasmatic reticulum across the mitochondrium, developing biogenetic granulums, followed by the stimulus-motivated secretum (exocytosis). The next stage of the molecular development is the specific break-up of the long polypeptid chains into shorter fragments. These fragments have individual effects. Some important clinical (diagnostic, prognostic) significance and connections are also touched upon in this paper, however, the cardiovascular, immunological systems and the tumors are mostly in focus. There are more immunological, cardio- 
vascular and tumoral data. It is stated that as these molecules are in close connection with all of the organisms and systems of the body, a new chief organisator system has been identified. This chief organisator is closely connected with the central nervous system.

Keywords: chromogranins, secretogranins, physiological, clinical relations

Jakab L. [Physiological, pathophysiological and clinical significance of chromogranins/secretogranins]. Orv Hetil. 2017; 158(28): 1092-1099.

(Beérkezett: 2017. április 3.; elfogadva: 2017. május 16.)

\begin{abstract}
Rövidítések
5-HT = 5-hidroxi-triptamin; Chrgr = kromogranin; CRP = C-reaktív protein; GI = gastrointestinalis; GI-flóra = gastrointestinalis flóra; GP = glikoprotein; Ig = immunglobulin; $\mathrm{IL}=$ interleukin; INF = interferon; Infl = inflammatio; ly = lymphocyta; $\mathrm{NOD}=$ nucleotide-binding oligomerization domain; $\mathrm{R}=$ receptor; $\mathrm{RR}=$ Riva - Rocci Segr = szekretogranin SERT = serotonin re-uptake transporter; TGF = transzformáló növekedési faktor; Toll-like $\mathrm{R}$ = transzmembrán glikoproteinmintázatot felismerő molekula; VIP = vazoaktív intestinalis peptid
\end{abstract}

A kromograninok (Chrgr-ok) és a szekretograninok (Segr-ok) hasonló biológiai struktúrák. Funkcionálisan rokon jelleg és egymással összefüggő szerepek jellemzik hatásaikat. A pontos humán élettani, klinikai szerepek feltárása még igen sok munkát igényel. Az bizonyos, hogy pontosan regulált, $\mathrm{Ca}^{++}$-dependens biogenetikusszekretoros képződési úttal, mechanizmussal alakulnak ki és választódnak el. A polipeptidek általában hormonális, neurotranszmitteres, növekedési faktorszerú, modulátor-mediátor hatásokkal rendelkeznek. Fontos szerepük van a szervezeti metabolizmus, glükózanyagcsere, az immunitás, cardiovascularis, neuroendokrin, gastrointestinalis rendszer, a magatartás és fájdalom regulációjában, továbbá a homeostasis fenntartásában. A gastrointestinalis rendszerben az epitheliumban legalább 15-féle endokrin, neuroendokrin sejttípus található. Ezek termelnek, exkretálnak metabolikumokat, amelyek különféle szerkezetû́, hatású anyagok. A biológiai diverzitás rendkívül széles körú. A gasztrin, enterokromaffin, szekretoros szomatosztatin, kolecitokinin, Chrgr/Segr csak mint egyedi példák említhetők [1-3].

\section{A Chrgr/Segr famíliatagok szerkezeti vonatkozásai}

A Chrgr-ok/Segr-ok egy hosszú polipeptidláncot alkotnak. A láncba több száz aminosav is beleépülhet. Leginkább prohormonnak tarthatók, és prohormonkonvertázok hatására módosulnak tovább sejt- és szövettípusspecifikus módon. A ChrgrA-polipeptidláncban 185637 aminosav lelhető fel, és legalább 10 helyen található dibázikus aminosav, amely hasítási helyként szolgálhat.
Az alapmolekula maga is rendelkezik többféle jelentős élettani, kórélettani szereppel, mégis az alapmolekula proteolyticus hasadási termékei azok, amelyek egyedi specifikus hatásokkal vannak felruházva. Ezek sem abszolút egyedi hatások, de azok rokon típusai. Fellelhetôk a különböző szervekben, vérben, liquorban. Egy polipeptid hasadási darabban is előfordulhat több dibázikus aminosav, amely talaja lehet további kisebb szegmentek képződésének. Nyilván specifikus sejtről, szövetenzimekről beszélhetünk, amelyek hasonlóan finom reguláció alatt állnak. A hormonok, neurotranszmitterek, neuropeptidek endokrin, neuroendokrin sejtekben és neuronokban történő keletkezésében és elválasztásában igen sok hasonlóság található. A neuroendokrin sejtekben intracellulárisan a durva endoplazmás reticulumban, azok ciszternáiban, majd a szekretoros granulumokban, a trans-Golgi-apparátusban, a tömör reticulumokban érnek be és kerülnek a megfelelő szignálok, stimulusok hatására regulált módon exkrécióra. A biogenezisben a granulumképzés alapvető fontosságú. A tömör vesiculumok száma 10000 és 30000 között változik egy tipikus endokrin, neuroendokrin sejtféleségben. A szekreció (exocytosis) mindig jellemző módon, stimulus hatására következik be $[1,3,4]$.

Itt szükséges megjegyezni, hogy mind a ChrgrA és B, mind a Segr-II láncszerkezetéhez oligoszacharid-csoportok kapcsolódnak. Ezek jellemző módon $\mathrm{N}$-acetil-galaktozamin révén kapcsolódnak a polipeptidlánchoz, és galaktózt és sziálsavat tartalmaznak. Ez utóbbi láncvégi pozícióban található. Érdekes, hogy a közlemények többsége meg sem említi, és a hivatkozók egyike sem bonyolódik bele ezek esetleges élettani/kórélettani jelentőségének taglalásába. Ismeretes, hogy a sziálsav domináns szereppel bír a felismerési/kötődési folyamatokban $[4,5]$. A lehasadt, önálló láncdarabok öröklik az eredeti hosszú láncok élettani hatásait. A különböző hosszúságú láncdarabok funkciója azonban nem determinált. Vannak, lehetnek rövid láncdarabok a legteljesebb, legtisztább funkcióval. A specifikus képződési hely (sejt, szövet) módosítja, meghatározza a hatás érvényesülését. A sajátos termelődési helytől függően lesz a hatásmód endokrin jellegú, parakrin vagy autokrin típusú. A termelődési hely az endokrin sejteken túl az egész testben, a neuroendokrin sejtekben keresendő. Ez utóbbia- 
kon túl szinte minden sejtféleség képessé válhat a szintézisre (transcytosis). Az élettani endokrin, neuroendokrin sejtek a bélhámban mindig egyediek. Az alapszöveti sejtektől adhéziós molekulák, például Notch-képződmény határolja el egymástól azokat. Itt jegyzendő meg, hogy Chrgr-okból neuropeptid és szekretoneurin nem eredeztethető $[5,6]$. A gastrointestinumban, az epitheliumban az 5-HT-termelő sejtek 75\%-a lelhető fel. A maradék az enterikus neuronokban, a bélfalban, az erekben, a szívben és a májban is lehet. Ennek megfelelően azt lehet mondanunk, hogy a gastrointestinalis rendszer a humán szervezet legnagyobb, legtömegesebb „neuroendokrin szerve". Tovább folytatva a gondolatsort, a szív- vagy az agyszövet is neuroendokrin szerv. A szerep betöltéséhez sine qua non az alacsonyabb pH-jú, $\mathrm{Ca}^{++}$-ot tartalmazó környezet. A kapcsolódási pont a megcélzott, vezérelt sejteken - stimulációt követően - akár receptor is lehet, de más „kellék” is szükséges, illetve elegendo" a celluláris kapcsolódáshoz. A ChrgrA és B különböző lánchosszúságú derivátumai, amint már fentebb említettük, fontosak a homeostasis, az élettani állapot fennmaradásában, rendeződésében, így többek között az élettani $\mathrm{pH}, \mathrm{Ca}^{++}$ és glükózanyagcsere, a naturális és szerzett immunitás regulációjában. Több Chrgr/Segr derivátum alapvető fontosságú élettani, kórélettani szereplő.

\section{A „graninok" és az immunrendszer}

A közlemények nagyobb része az inflammatióval (Infl) kapcsolatban foglalkozik a Chrgr-okkal, az immunrendszer egységes értelmezése és tárgyalása a háttérben marad. Az élő szervezetben az individuum épségének védelme az immunrendszerre hárul. Ennek két funkcionális „karja” van. A veleszületett vagy naturális immunitás és a szerzett vagy adaptív immunitás. A naturális immunválasz és az Infl identikus fogalmak, folyamatok. Az Infl az adaptív immunválasszal egymást támogatva, a legszorosabban együttmúködve, összehangolva lépnek és maradnak összeköttetésben. A feladat az orgánumot ért ártalom, inzultus (külső, belső) elhárítása, a szervezet integritásának helyreállítása, megóvása. Ebben a tevékenységben az immunrendszer szigorú reguláció (cortex, hypothalamus, hypophysis, glandula suprarenalis) mellett múködik, továbbá bekapcsolódik a vegetatív, autonóm idegrendszer is. A neuroendokrin rendszer hasonlóan nélkülözhetetlen az elhárító, helyreállító válasz formálásában. Természetesen az immunrendszer mindkét ága, együttmúködése lehet tökéletes vagy tökéletlen. Ebben az esetben a védelemre berendezkedett immunrendszer egyik „karja”, az Infl-s folyamat válik „kórokozóvá", esetleg az individuum halálát okozva. A deficiens és hiperaktivitás egyaránt kóros. Pneumoniáról beszélünk, pedig a beteg baját a szervezetbe jutott pneumococcusok okozzák, amely ellen a védekezés eszköze a „pneumonia” $[6,7]$.

A GI-rendszer napi céltáblája lehet a szervezetet éró noxáknak és esetleg apparens Infl létrejöttének. Itt alakul ki a naturális és adaptív immunitás első védelmi vonala. Mind a nem specifikus, mind a specifikus válasznak szilárd alapjai alakultak ki a phylogenesis során. A humán organizmus összes sejtjeinek száma $10^{12}\left(10^{14}\right.$ gén expressziója). A commensalis bélflóra tömege $10^{14}$ ( $10^{4}$ gén expressziója) sejt. A GI-flóra és a saját sejtek a funkcionális metabolitok sokféleségét produkálják, ami bejut a béltartalomba. Köztük vannak a Chrgr-ok/Segrok (bacteribolom, metabolom). A GI szekretorikus sejtek, paneth, goblet, neuroendokrin, az összes sejt mintegy 1\%-át teszik ki. Az oxynticus ventricularis szövetben négy endokrin sejttípus lelhető fel. Ezek szerotonint, hisztamint, szomatosztatint és ghrelint termelnek $[8,9]$. A szervezet 5-HT-tartalmának 95\%-a van a GI-rendszerben, körülbelül 10\%-a a neuronokban. A bél-baktériumflóra jelentős mennyiségú, profibrotikus hatással bíró metabolitokat produkál, ami az apparens és nem apparens Infl eseteiben rendkívül fontos. Ebben az extracellulárismátrix-anyagcserében nem csak a fibroblastok tevékenyek a transzformáló növekedési faktor (TGF) stimulációs hatására [9]; a máj, a belek, a stellata sejtek mellett a mesenchymalis (transcytosis) sejtek is gazdag forrásai a proteoglikánoknak és más mátrixmetabolitoknak (fibronektin, laminin). Helicobacter pylori okozta krónikus infekció és Infl alig jár fibrosissal. Hasonlóan sine fibrosissal jár a gluténszenzitív enteropathia. Nem így a paranchymás szervek esetében (máj, vesék): a TGF és az epidermalis growth factor gátolják a gyomor parietalis sejtjeinek múködését és a sósavszekréciót [10-12]. Peptiderg regulációs tényezők a hisztamin, szomatosztatin, neurotenzin, vazoaktív intestinalis peptid (VIP) parakrin-endokrin módon hatnak. A sejtek mozgását, vándorlását kemokinek, adhéziós molekulák, citokinek bonyolítják, a sejtek membránján többek között NODés Toll-like R-ok múködnek közre. A termelődött anyagok, a bélflóra és az egyéb matéria mellett jelentik, alkotják a teljesen heterogén gyomorbéltartalmat. A CD4 lymphocyták (ly-k) kapcsolatba lépnek az endokrin, neuroendokrin és más prekurzor sejtekkel. Növelhetik például az 5-HT-produkciót. Enteralis infekciókban Thl és Th2 ly-dominancia egyaránt előfordul. Az 5-HT-produkciót a Th2 ly-k fokozzák inkább, ami a naturális immunválasz indukcióját jelenti. Szerotoninerg R-ok találhatók a ly-k mellett monocyta-macrophag és dendritikus sejteken is. A neuroendokrin sejtek szoros kapcsolatban vannak például a CD-3 és a CD-20 ly-kal. Az 5-HT elősegíti a T-sejt-szaporodást, gátolja a ly-apoptózist. A kapcsolat hátterében szerotonin reuptake transzporter (SERT) áll, ami a megtermelt anyagok szállítását segíti elő az epithelium- és a simaizomsejtekbe, továbbá a neuronokba. CD-17 regulátor ly-k kimutathatók az intestinalis erekben. Rendkívül fontos a GI-traktusban termelődő szekretoros IgA funkciója. Ez egy nagy szekretoros komponenst hordozó dimer molekula. Az alapmolekula - különösen a szekretoros komponens - igen gazdag oligoszacharidokban és sziálsavban. Fontos tudni, hogy a mindennapos védekezés mellett az IgAl-molekulák 
szövetben való lerakódása okozza az IgA-nephropathiát. Előfordulnak szérum-IgA- és szekretoros IgA-deficiens individuumok. A lerakódásban az oligoszacharid-láncok kissé változott módosulása a döntő jelentőségű. Antiinfekciós hatása általános jellegú [13-17].

A mastocyták rendkívül fontos sejtalakzatok. Az immunrendszer szerves alkotóiként gazdag szekréciós és tárolási kapacitással rendelkeznek. Egyik egészen sajátos produktumuk és tároltjuk a serglicin proteoglikán. Sokféle metabolit termelődik, tárolódik a molekulákban. Ezek közé tartoznak a tárolt szerotonin, heparin és hisztamin. Esetleges direkt kapcsolata a Chrgr-okkal/Segrokkal nem tisztázott [18-21].

A szekretált, a béltartalomban gomolygó metabolitok összessége a metabolom. A commensalis flóra összetételének megváltozása, külső patogén mikroorganizmusok bejutása infekciót és Infl-t gerjeszthet. Az egyértelmúen exogén infekciózus folyamatok mellett találkozhatunk colitis ulcerosával, enteritis regionalisszal (sec Crohnszindróma), irritábilis intestinalis szindrómával, atopiás dermatitissel. A Chrgr-ok/Segr-ok in principio részt vesznek a folyamatokban, a Chrgr-okon/Segr-okon túl a proteolyticus derivátumaik is fontos résztvevők. A derivátumok közül a prokromacin, a kromacin, a kromofungin (b ChrgrA 47-66) és a vazosztatin (b Chrgr 1-76) emelhetők ki az antiinfekciózus-antiinflammatorikus hatóanyagok között. Szükséges megemlíteni a katesztatint (b Chrgr 344-364), amely kemotaktikus hatást gyakorol a monocytákra. Szekretoneurin eosinophil sejtekben található és csökkenti az IL-16 felszabadulását. A jelenség granulocyta-macrophag kóloniastimuláló faktorral és IL-5-tel is összefügg (serglicin) [22-24].

Autoinflammatorikus febris szindrómában rengeteg proinflammatorikus kemokin és citokin kiáramlása észlelhető. Előfordulhat IL-1 túlzott szignalizációs folyamat is. Ez naturális immunválaszra utal. A jelenség hátterében fokozott INF tip. l-kiáramlás is állhat. Monogénes folyamat esetében előfordulhat a vérben INF- $\alpha$ - és INF-R-felszaporodás. A Chrgr szerepe még nem tisztázott, kutatás tárgyát képezi. A szakirodalomban említésre került már gigantocellularis arteritis, kortikoszteroidrezisztanciával és fokozott Chrgr-termeléssel. Elöfordulnak autoreaktív CD4T ly-k, de ezek szerepe sem tisztázott teljesen. A Chrgr és származékai nemcsak szabályozzák az immunfolyamatokat, hanem megváltoztatják az epithelium és vasculatura permeabilitását. Hatásukra - kísérleti körülmények között - csökken a vascularis permeabilitás. A vazosztatin csökkenti az oedemát. A Chrgr fokozott szérumkoncentrációjának növekedését a neuroendokrin sejtek hyperplasiája magyarázza. A colonfalban IL-1 $\beta$, IL- 6 és TGF- $\alpha$ megemelkedett mennyiségének csökkenése mutatható ki kísérletekben katesztatin hatására. Korrelációt figyelhetünk meg a Chrgr-, a TNFRI- és TNFRII-mennyiség és -változás között. Bár az anti-TNF- $\alpha$ monoklonális Ig-terápia a korrelációt megszünteti, valójában ismeretlen faktorok közbejötte tételezhető fel. A szérum-Chrgr-koncentráció és -hatás független a szisztémás inflammatorikus válasz jelenlététől. A szérum-ChrgrA mennyisége pozitív összefüggést mutat a prokalcitonin és a CRP-szinttel. A ChrgrA (b ChrgrA 4-16 és 47-67) peptidderivátumok pro-, illetve antinociceptív effektusokat képesek produkálni [25-27].

\section{A cardiovascularis rendszer és a Chrgr-ok}

Úgynevezett esszenciális hypertensióban a szimpatikus idegrendszer fokozott aktivitása mellett emelkedett a szérum-ChrgrA koncentrációja. Ugyanakkor a katesztatinszint alacsony még akkor is, amikor az RR-értékek az élettani zónában mozognak. A katesztatin csökkenti, gátolja a kromaffinsejtek múködését. Azokban a családokban, amelyekben örökletes hypertensióról van szó, a szérumkatesztatin koncentrációja alacsony, az epinefrinkoncentráció pedig magas [28-31]. Úgy túnik, hogy a hypertensio létrejöttében, kialakulásában a Chrgr szerepe vitathatatlan, és ez összefüggésben lehet azzal is, hogy az eredeti Chrgr-molekula milyen mértékben hasítódott specifikus hatású derivátumokra. A normális tenzióhoz elengedhetetlen a normális Chrgr-funkció. A cardiovascularis rendszer és a központi idegrendszer a corticohypothalamus-hypophysis-adrenalis axis és az autonóm idegrendszer révén szoros kapcsolatban állnak. Erre Cannon (vészreakció) és fóként Selye (általános adaptációs szindróma) munkássága mutatott rá először [32-34]. A diffúz neuroendokrin rendszer szerepét az tanúsítja, hogy a Chrgr együtt-tárolódás után az exocytosis során együtt szabadul fel a katecholaminokkal, más transzmitterekkel és polipeptid- (neurin-) dilatatorokkal. A katesztatin hatékony vasodilatator (a vazosztatinnal együtt). Ugyanakkor a vazosztatin kardioinhibitor. A vazosztatin hatékony gátlója a katecholaminfelszabadulásnak, mert gátolja a nikotinkolinerg R-t. A hatásmód autokrin és parakrin. A szekretoneurin egy Segr-II-derivátum, dopaminfelszabadulást indukál, proinflammatorikus jellegú, vascularis simaizomsejt-migráció és -proliferáció-stimuláns. Egy szekretoneurinszármazék szelektíven gátolja az orexinneuropeptid-hatást a thalamusban [34-36]. A vazosztatin-I kardiális hatása negatív inotropia és negatív lusitropia formájában mutatkozik meg leginkább. A katesztatin kardiális hatásai hasonlóan nyilvánulnak meg, ugyanakkor hatékonyan csökkenti az RR-t. A ChrgrAkoncentráció emelkedése egyértelmúen jelzi az infarctus myocardii acutát és az akut arteria coronaria szindróma esetlegesen várható halálos kimenetelét. A vérbeli koncentráció jelentôs emelkedése bármely típusú és eredetû cardialis dekompenzáció esetén prognosztikus értékű. A ChrgrB cardiovascularis hatásai kevésbé egyértelmúek. Az egyik Segr-II-derivátum stimulálja a simaizomsejtmigrációt és -proliferációt [37-40]. Különös figyelmet érdemel egy Chrgr-származék, a serpinin, amely szintén neuroendokrin és kromaffinsejtek produktuma. Egy 29 kD tömegú ChrgrA C-terminális fragmentuma, 26 tagú aminosavpeptid stimulálja a proteinase nexin 1 képződé- 
sét. Serpinfamília tagsága miatt nyerte el a serpinin megjelölést. Bioaktív származék, regulálja a neuroendokrin sejtekben, a tömör magvakban a granulumképződést. Bizonyos tulajdonságbeli rokonság fedezhető fel a bioaktív peptidekkel (leptin, ghrelin, lakrinin, epidermalis növekedési faktor). A vizsgált ChrgrA-peptidek közül (katesztatin, pankreasztatin, parasztatin, kromasztatin) csak a serpinin indukálta a protease nexin l-aktivitást. A serpinin kifejezetten kedvező hatásokkal rendelkezik: a hatás lényege a $\beta$-andrenerg-agonista jellege, ami $\beta 1$ andrenerg R-okon keresztül valósul meg. A pozitív inotrop és lusitrop effektus jelentősen javítja a mechanikus kardiális teljesítményt; növekszik a szisztolés kamrai volumen, rövidül a diasztolés idő, továbbá tachycardiatendencia érvényesül és tágulnak az arteria coronariák. Állatkísérletben mutatkozik meg az intracardialis autokrin, parakrin hatásbeli út (ChrgrA-proteolysis, serpininképződés, szívizomhatás, kardiális teljesítmény növekedése) [41-44]. Az eredmény szinte teljesen ellentétes a katesztatin- és vazosztatinhatásokkal. Keringési elégtelenségben, infarctus myocardiiben, úgynevezett akut arteria coronaria szindrómában mindig emelkedik a ChrgrA szérumszintje, sőt prognosztikus jelentőséggel bír. A cardiomyocyták maguk is termelik a Chrgr-okat aktív folyamatokban.

\section{A Chrgr-ok/Segr-ok egyéb kórfolyamatokban}

Ha ki akarnánk emelni a tárgyalt kémiai szerkezetek legfőbb funkcionális tulajdonságait, akkor talán a granulumbiogenezisben játszott granulogenetikus szerepüket és a sympathoadrenalis rendszer aktivitási regulációját említhetnénk. Így válik lehetővé a szekretoros felszabadulás, az exocytosis, amelyre minden sejttípus alkalmassá válhat in periculo. Sajátos források a neuroendokrin sejtek, amelyek mindenkor termelik ezeket, de hyperplasia, adenomás megjelenés és malignus elfajulás esetén fokozódhat a termelőkapacitás. A sejtek jelen vannak az idegrendszerben, különböző szövetekben és a neuroendokrin tumorokban; a Segr az adrenalis modullában, a hypophysis hátsó lebenyében, a neuroendokrin és idegsejttumorokban található. Fellelhetók gastriticus enterokromaffin jellegü hyperphasia esetén, a glandula parathyreoidea szövetben. A neuroendokrin tumorok jellemző szekrétumos origói, így tulajdonképpen a Chrgr, Segr-II-V a legfontosabbak. A Chrgr a phaeochromocytomában a benignus/malignus jelleg megítélésében is segítség, de a ChrgrB- és Segr-szint is megemelkedik: a Chrgr carcinoid tumorban 1000-szeres emelkedést mutathat. Pancreastumorban a glükagon-, a szomatosztatin- és a VIP-koncentráció-emelkedés jellemző a szérumban. A gasztrinmediált enterokromaffinsejt-hyperplasia, Zollinger-Ellison-szindróma hasonlóan lelőhely lehet. Prostatatumor jelenlétében normális PSAszint mellett is emelkedést találhatunk a Chrgr-szintben. Colon-, rectum-, mammatumor, melanoma malignum, thymoma során hasonló a helyzet [44-47]. A nem funkcionáló tumorok között a glandula thyreoidea medulla, hipofízis elülső lebeny szindróma, valamint pulmonalis kissejtes carcinoma járhat megemelkedett szérumszinttel.

Parkinson-szindrómában a liquorszint csökken, ugyanakkor deponálódik a substantia nigrában. De jelentôsen felgyülemlik a szenilis és Alzheimer-plakkokban, továbbá Pick-szindrómában a megduzzadt neuronokban. Ezekben az esetekben a microgliasejtek aktivitása jelentős közvetítő lehet [45-47]. Szkizofréniában kevesebb ChrgrA és B található a liquorban. A protonpumpagátló szerek jelentősen megemelik a szérum ChrgrA-szintjét, miközben a ChrgrB-szint nem változik. A szervi betegségek között a máj- és különösen a vesebetegség érdemel kiemelést, a már említett kardiális keringési elégtelenség melletti fokozott szérum-Chrg-tartalom miatt. Különösen feltünő jelenség a keringési elégtelenség IV. stádiumában. Vérkoncentrációs emelkedéssel jár a szepszis, a gastritis atrophicans, a metabolikus szindróma és a diabetes mellitus. A pankreasztatin gátolja az inzulinszekréciót a lipogenesissel együtt. A katesztatin ezzel ellentétes hatású - gátolja az angiogenesist és jelentősen rontja az endotheliumpermeabilitás épségét. Az endotheliumátjárhatóság fokozódásában a Chrgr is jeleskedik [2, 3, 32]. A tumorok vascularisatiója feltúnően rendezetlen, esetleg elégtelen. A vascularis endothelium permeabilitását az adhéziós molekulák és a mátrixproteoglikánok mennyiségi, összetételi változásai határozzák meg, ami a tumorok terápiáját is jelentősen befolyásolhatja. Érdekes megfigyelés a Merkel-sejtes tumorokban észlelt Chrgr/Segr anyagcserezavar. Tóth tollából jelent meg egy nagyon részletes összefoglaló az endokrin tumorok terápiájáról; ebben az igen hasznos közleményben a „CgA” és a „kromogranin-A” csak érintőlegesen fordul elő [48]. Hasonló jellegú Perge és mtsai összefoglalója, döntően a szomatosztatinanalógokkal kapcsolatos ismeretekről, amelyben a biomarkerek között kerül említésre a kromogranin-A [49] (1. táblázat).

\section{Következtetések (epilógus)}

Kissé merész vállalkozás a Chrgr-ok/Segr-ok és derivátum metabolitjaikról összefoglaló jellegú értelmezésre, értékelésre vállalkozni. Megjelenésük az irodalomban már meghaladta a 20 évet. A haladás ehhez képest is lassúnak mondható, és máig nehezen jutott túl a serdülökoron. A részadatok száma nem kevés, de az inherens összefüggések, az egyes szervrendszerekkel való kapcsolódások feltárása, a klinikummal való egyértelmú összhang megteremtése még jelentős részben hátravan. Itt nemcsak a teoretikus, egzakt ismeretek logikus összeillesztéséről van szó - a döntő kérdés egy sui generis nagy rendszer értelmezése és annak más rendszerekkel történő együttmúkködésének magyarázata. Mindemellett a gyakorlati felhasználhatóságot is szükséges pontosabban körvonalazni, amihez már ma is rendelkezésre állnak di- 
Kromograninok, szekretograninok, derivátumok, funkcionális társmolekulák

\begin{tabular}{|c|c|c|c|}
\hline & Aminosav & $\begin{array}{l}\text { Molekula- } \\
\text { tömeg }(\mathrm{kD})\end{array}$ & Sajátosság \\
\hline I. Kromogranin-A & 489 & 75 & O-glikoziláció \\
\hline II. Kromogranin-B & 657 & 110 & $\begin{array}{l}\text { N- és } \\
\text { O-glikoziláció }\end{array}$ \\
\hline III. Szekretogranin-II & 587 & 86 & O-glikoziláció \\
\hline $\begin{array}{l}\text { IV. Szekretogranin- } \\
\text { III }\end{array}$ & 449 & 57 & Koleszterinkötés \\
\hline $\begin{array}{l}\text { V. Szekretogranin- } \\
\text { IV (7B2 protein) }\end{array}$ & 186 & 201 & Konzervált régiók \\
\hline $\begin{array}{l}\text { VI. Szekretogranin-V } \\
(\text { NESP 55) }\end{array}$ & 201 & 28 & $\begin{array}{l}\text { Maternális allél } \\
\text { átírva } \\
\text { ProAAS rokon }\end{array}$ \\
\hline $\begin{array}{l}\text { VII. Szekretogranin- } \\
\text { VI (VGF) }\end{array}$ & 593 & 90 & O-glikoziláció \\
\hline $\begin{array}{l}\text { VIII. Szekretogranin- } \\
\text { VII. (proAAS) }\end{array}$ & 227 & 27 & $\begin{array}{l}7 \mathrm{~B} 2 \text { rokon, } \\
\text { konzervált régiók }\end{array}$ \\
\hline
\end{tabular}

\begin{tabular}{|c|c|}
\hline 1. Katesztatin & Chrgr-derivátum \\
\hline 2. Kateszlitin & Chrgr-derivátum \\
\hline 3. Katepszin-L & Chrgr/Segr képződés \\
\hline 4. Cecropin & $\begin{array}{l}\text { Chrgr/Segr derivátum, } \\
\text { antimikrobális hatás }\end{array}$ \\
\hline 5. Clathrin & Granulummembrán \\
\hline 6. Kromofungin & Chrg/Segr derivátum, antiinfekció \\
\hline 7. Cholecystokinin & Gastrointestinum, hormon \\
\hline 8. Kromosztatin & Chrg/Segr derivátum, antiinfekció \\
\hline 9. Kromacin & Chrg/Segr derivátum, antiinfekció \\
\hline 10. Cytochalasin D & Aktinpolimerizáció-inhibitor \\
\hline 11. Defenzin & Granulocyta, antimikrobális peptid \\
\hline 12. Dermatoszeptin & Granulocyta, antimikrobális peptid \\
\hline $\begin{array}{l}\text { 13. Epidermalis growth } \\
\text { factor (EGF) }\end{array}$ & Gyomorsósavtermelés-gátlás \\
\hline 14. Endothelin & $\begin{array}{l}\text { Endothelium termelte hormon, } \\
\text { vérkeringés befolyásolása }\end{array}$ \\
\hline 15. Encephalin & Bioaktív polipeptidhormon \\
\hline 16. Ezrin & Kapcsolat a phophoprotein 50-nel \\
\hline 17. Ezrin-radixin-moesin & Membrán cytoskeleon adaptor \\
\hline 18. Fibronektin & Mátrixkomponens GP \\
\hline 19. Galanin & Mastocytatermék, metabolit \\
\hline 20. Galaparan & Mastocytatermék, metabolit \\
\hline 21. Ghrelin & Kromaffinsejtekből, bioaktív peptid \\
\hline 22. GIP & $\begin{array}{l}\text { Gastrointestalis (duodenum) } \\
\text { metabolit, peptid }\end{array}$ \\
\hline 23. Lakritin & Kromaffinsejt-termék \\
\hline 24. Laminin & Mátrixkomponens GP \\
\hline 25. Leptin & Kromaffinsejt-termék, bioaktív peptid \\
\hline 26. Manserin & Segr-II-termék \\
\hline 27. Mastoparan & Mastocytaderivátum, R-szerú funkció \\
\hline
\end{tabular}

28. Magainin

29. Neuroendokrin secretory protein (NESP)

30. Neuropilin

31. Neurotrophin

32. Orexin

33. Parasztatin

34. Protein C

35. Phospholamban

36. PNl

37. Prokromacin

38. Proenchephalin

39. Proopiomelanokortin

40. Relaxin

41. Szekritin

42. Szerotonin

43. Szekretoneurin

44. Szekretolitin

45. Scorpin

46. Serglicin

\section{Serpinin}

48. Synaptogranin IV

49. Staurosporin-IV

50. Transforming growth factor

51. Ubigranin

52. Vazosztatin

53. Vehicle associated membran protein

54. VIP

55. VEGF
Antimikrobális peptid

Bioaktív peptid

Microglia R, köt: semaphorin, VEGF

Citokin

Segr-II-derivátum

Chrgr/Segr derivátum

Proteinkonvertáz

Inotrop-lusitrop hatások, regulator peptid

Proteáz-nexin (serpininképződés)

Chrgr/Segr derivátum, antimikrobális hatás

„Nagy” propolipeptid

„Nagy" propolipeptid

Bioaktív peptid

Segr-derivátum

Kromaffinsejt-termék

Segr-derivátum

Segr-derivátum, antimikrobális hatás Antimikrobális peptid

Mastocytában szénhidrátgazdag proteoglyca, endothelium, Mo, Ma

Chrgr-derivátum

Chrgr-derivátum

Sejtgranulum-membrán

Gyomorsósavelválasztás-gátlás, anti-TNF, alapvető citokin

Chrgr/Segr derivátum

Chrgr/Segr derivátum

Granulummembránalkatrész-protein

Vazoaktív intestinalis peptid

Vascular endothelial growth factor

agnosztikus és prognosztikus értékủ adatok. Az bizonyosnak látszik, hogy az egész individuumot érintő, meghatározó, a neuropszichikumot is befolyásoló rendszer jelenléte körvonalazódik, ami tulajdonképpen a központi és a vegetatív idegrendszer, a neuroendokrin rendszer, az immunitás, a gastrointestinum és a cardiovascularis rendszer múködését szabályozó szerkezet és ezek eleven „organizmusa”. A jövő feladata lesz választ találni az ezeket mozgató, szabályozó, eddig „alvó” rendszer mibenlétére. Egy, az eddigiek sorába illő új rendszerrel állunk szemben, de az is lehet, hogy egy újszerü, az eddig ismert rendszereket összeillesztő vagy netán egy minőségileg új „szuperrendszerről” kell beszélnünk. Ha az utóbbi feltételezés bizonyosodik be, akkor esetleg az individuum egységének újraértelmezéséről kell majd szólnunk. A nagy feladat elvégzése, még ha 
kissé nehéznek tûnik is, a klinikumba való szerves beépítése nélkül nem remélhető. A biokémiai, biofizikai adatok értelmezése elkerülhetetlen ahhoz, hogy olyan mechanizmusok kerüljenek napvilágra, amelyek lehetővé teszik a patológiai folyamatok megértését, a diagnosztikus, terápiás vonatkozások összesítését, alkalmazását.

Anyagi támogatás: A közlemény megírása anyagi támogatásban nem részesült.

A cikk végleges változatát a szerző elolvasta és jóváhagyta.

Érdekeltségek: A szerzőnek nincsenek érdekeltségei.

\section{Irodalom}

[1] Koshimizu H, Kim T, Cawley NX, et al. Chromogranin A: A new proposal for trafficking, processing and induction of granule biogenesis. Regul Pept. 2010; 160: 153-159.

[2] Taupenot L, Harper KL, O'Connor DT. The chromogranin-secretogranin family. NEJM 2003; 348: 1134-1149.

[3] Bartolomucci A, Possenti R, Mahata SK, et al. The extended granin family: structure, function, and biomedical implications. Endocr Rev. 2011; 32: 755-797.

[4] Loh YP, Cheng Y, Mahata SK. Chromogranin A and derived peptides in health and disease. J Mol Neurosci. 2012; 48: 347356.

[5] Jakab L. Biological role of heterogeneous glycoprotein structures. [A heterogén glikoproteinszerkezetek biológiai szerepe.] Orv Hetil. 2016; 157: 1185-1192. [Hungarian]

[6] Sørensen AL, Rumjantseva V, Nayeb-Hashemi S, et al. Role of sialic acid for platelet life span: exposure of beta-galactose results in the rapid clearance of platelets from the circulation by asialoglycoprotein receptor-expressing liver macrophages and hepatocytes. Blood 2009; 114: 1645-1654.

[7] Jakab L. The way of self-defence of the organism: inflammation. [A szervezeti önvédelem módja: a gyulladás.] Orv Hetil. 2013; 154: 1247-1255. [Hungarian]

[8] May C, Kaestner KH. Gut endocrine cell development. Mol Cell Endocrinol. 2010; 323: 70-75.

[9] Varga J, Pasche B. Transforming growth factor beta as a therapeutic target in systemic sclerosis. Nat Rev Rheumatol. 2009; 5: 200-206.

[10] El-Salhy M, Gilja OH, Gundersen D, et al. Endocrine cells in the oxyntic mucosa of the stomach in patients with irritable bowel syndrome. World J Gastrointest Endosc. 2014; 6: 176-185.

[11] Grupcev G, Wallin C, Emås S, et al. Transforming growth factoralpha and epidermal growth factor inhibit gastric acid secretion and stimulate release of somatostatin and neurotensin in the conscious rat. Regul Pept. 1994; 52: 111-118.

[12] Khan W, Ghia JE. Gut hormones: emerging role in immune activation and inflammation. Clin Exp Immunol. 2010; 161: 1927.

[13] Rudholm T, Wallin B, Theodorsson E, et al. Release of regulatory gut peptides somatostatin, neurotensin and vasoactive intestinal peptide by acid and hyperosmolal solutions in the intestine in conscious rats. Regul Pept. 2009; 152: 8-12.

[14] Ferrero E, Scabini S, Magni E, et al. Chromogranin A protects vessels against tumor necrosis factor $\alpha$-induced vascular leakage. FASEB J. 2004; 18: 554-556.

[15] Vaingankar S, Li Y, Biswas L, et al. Effects of chromogranin A deficiency and excess in vivo: biphasic blood pressure and catecholamine responses. J Hypertens. 2010; 28: 817-825.
[16] Mazza R, Imbrogno S, Tota B. The interplay between chromogranin A-derived peptides and cardiac natriuretic peptides in cardioprotection against catecholamine-evoked stress. Regul Pept. 2010; 165: 86-94.

[17] Boltjes A, van Wijk F. Human dendritic cell functional specialization in steady-state and inflammation. Front Immunol. 2014; 5: 131.

[18] Melo FR, Vita F, Berent-Maoz B, et al. Proteolytic histone modification by mast cell tryptase, a serglycin proteoglycan-dependent secretory granule protease. J Biol Chem. 2014; 289: 76827690 .

[19] Kolset SO, Tveit H. Serglycin - structure and biology. Cell Mol Life Sci. 2008; 65: 1073-1085.

[20] Skliris A, Happonen KE, Terpos E, et al. Serglycin inhibits the classical and lectin pathways of complement via its glycosaminoglycan chains: implications for multiple myeloma. Eur J Immunol. 2011; 41: 437-449.

[21] Jones S, Howl J. Biological applications of the receptor mimetic peptide mastoparan. Curr Protein Pept Sci. 2006; 7: 501-508.

[22] Haniffa M, Gunawan M, Jardine L. Human skin dendritic cells in health and disease. J Dermatol Sci. 2015; 77: 85-92.

[23] Jakab L. The liver and the immune system. [A máj és az immunrendszer.] Orv Hetil. 2015; 156: 1203-1213. [Hungarian]

[24] Bajor J. Coeliakia - Update 2016. [Coeliakia - 2016.] Magy Belorv Arch. 2016; 69: 321-327. [Hungarian]

[25] Vokaer B, Van Rompaey N, Lemaittre PH, et al. Critical role of regulatory $\mathrm{T}$ cells in Th17-mediated minor antigen-disparate rejection. J Immunol. 2010; 185: 3417-3425.

[26] Wang R, Zhu J, Dong X, et al. GARP regulates the bioavailability and activation of TGF $\beta$. Mol Biol Cell 2012; 23: 1129-1139.

[27] Németh J. Laboratory tests of fecal samples in gastrointestinal diseases. [Székletvizsgálatok emésztőrendszeri betegségekben.] Magy Belorv Arch. 2015; 68: 230-234. [Hungarian]

[28] Mahata SK, Mahata M, Fung MM, et al. Catestatin: a multifunctional peptide from chromogranin A. Regul Pept. 2010; 162: $33-43$.

[29] Di Comite G, Morganti A. Chromogranin A: a novel factor acting at the cross road between the neuroendocrine and the cardiovascular systems. J Hypertens. 2011; 29: 409-414.

[30] Biswas N, Rodriguez JL, Courel M, et al. Cathepsin L colocalizes with chromogranin A in chromaffin vesicles to generate active peptides. Endocrinology 2009; 150: 3547-3557.

[31] Allu PK, Venkat R, Chirasani V, et al. Naturally occurring variants of the dysglycemic peptide pancreastatin. Differential potencies for multiple cellular functions and structure-function correlation. J Biol Chem. 2014; 289: 4455-4469.

[32] Filer CE, Ho P, Bruce IN, et al. High blood levels of chromogra$\operatorname{nin} \mathrm{A}$ in giant cell arteritis identify patients refractory to corticosteroid treatment. Ann Rheum Dis. 2009; 68: 293-295.

[33] Biswas N, Vaingankar SM, Mahata M, et al. Proteolytic cleavage of human chromogranin A containing naturally occurring catestatin variants: differential processing at catestatin region by plasmin. Endocrinology 2008; 149: 749-757.

[34] Røsjø H, Husberg C, Dahl MB, et al. Chromogranin B in heart failure: a putative cardiac biomarker expressed in the failing myocardium. Circ Heart Fail. 2010; 3: 503-511.

[35] Helle KB. The chromogranin A-derived peptides vasostatin-I and catestatin as regulatory peptides for cardiovascular functions. Cardiovasc Res. 2010; 85: 9-16.

[36] Tota B, Angelone T, Mazza R, et al. The chromogranin A-derived vasostatins: New players in the endocrine heart. Curr Med Chem. 2008; 15: 1444-1451.

[37] Angelone T, Quintieri AM, Brar BK, et al. The antihypertensive chromogranin A peptide catestatin acts as a novel endocrine/ paracrine modulator of cardiac inotropism and lusitropism. Endocrinology 2008; 149: 4780-4793. 
[38] Pieroni M, Corti A, Tota B, et al. Myocardial production of chromogranin A in human heart: a new regulatory peptide of cardiac function. Eur Heart J. 2007; 28: 1117-1127.

[39] Fiocchi C, Lund PK. Themes in fibrosis and gastrointestinal inflammation. Am J Physiol Gastrointest Liver Physiol. 2011; 300: G677-G683.

[40] Shooshtarizadeh P, Zhang D, Chich JF, et al. The antimicrobial peptides derived from chromogranin/secretogranin family, new actors of innate immunity. Regul Pept. 2010; 165: 102-110.

[41] Koshimizu H, Cawley NX, Yergy AL, et al. Role of pGlu-serpinin, a novel chromogranin A-derived peptide in inhibition of cell death. J Mol Neurosci. 2011; 45: 294-303.

[42] Jansson AM, Rosjo H, Omland T, et al. Prognostic value of circulating chromogranin A levels in acute coronary syndromes. Eur Heart J. 2009; 30: 25-32.

[43] Tota B, Gentile S, Pasqua T, et al. The novel chromogranin Aderived serpinin and pyroglutaminated serpinin peptides are positive cardiac $\beta$-adrenergic-like inotropes. FASEB J. 2012; 26: 2888-2898

[44] Koshimizu H, Cawley NX, Kim T, et al. Serpinin: A novel chromogranin A-derived, secreted peptide up-regulates protease nexin- 1 expression and granule biogenesis in endocrine cells. Mol Endocrinol. 2011; 25: 732-744.
[45] Stadinski BD, Delong T, Reisdorph N, et al. Chromogranin A is an autoantigen in type 1 diabetes. Nat Immunol. 2010; 11: 225231.

[46] Nobels FR, Kwekkeboom DJ, Bouillon R, et al. Chromogranin A: its clinical value as marker of neuroendocrine tumours. Eur J Clin Invest. 1998; 28: 431-440.

[47] Dejda A, Mawambo G, Cerani A, et al. Neuropilin-1 mediates myeloid cell chemoattraction and influences retinal neuroimmune crosstalk. J Clin Invest. 2014; 124: 4807-4822.

[48] Tóth M. Therapeutic options for the treatment of neuroendocrine tumours. [A neuroendokrin tumorok kezelésének lehetőségei.] Lege Artis Med. 2013; 23: 503-516. [Hungarian]

[49] Perge P, Decmann Á, Igaz P. Somatostatinanalogues in the treatment of neuroendocrine tumours. [A neuroendokrin daganatok kezelése szomatosztatinanalógokkal.] Magy Belorv Arch. 2015; 68, 317-322. [Hungarian]

(Jakab Lajos dr., Budapest, Kútvölgyi út 4., 1125 e-mail: nyulikinga@gmail.com)

\section{Ellen Notbohm-Veronica Zysk} EZEREGY NAGYSZERRUU ÖTLET AUTIZMUSSAL ÉLŐ VAGY ASPERGER-SZINDRÓMÁS GYEREKEK NEVELÉSÉHEZ ÉS TANÍTÁSÁHOZ

„Ha minden iskolában és családban a könyvben szereplő ötletek kis töredékét felhasználnák, beláthatatlan lehetöségek nyilinának meg elöttünk, hogy javítsuk az autizmussal vagy Asperger-szindrómával élö gyermekek életminőségét. Ez pedig csodálatos dolog!"

A könyv számtalan azonnal alkalmazható ötletet kínál szülőknek és nevelőknek az alábbi területeken:

- szenzoros integráció: fejlesztőfeladatok a szabadban és bent,

- kommunikáció: szóhasználat, hallás, vizualitás, környezet,

- viselkedés: tipikus viselkedési formák és kezelésük,

- mindennapi élet: ötletek a mindennapi szituációkhoz, a biztonság megteremtéséhez,

- szociális létezés: barátság, játék, kooperáció, érzelmek.

\section{Dr. Temple Grandin}

